\title{
A PROTEIN FACTOR ASSOCIATED WITH SERUM RESISTANCE IN ESCHERICHIA COLI
}

\author{
P. W. TAYLOR* $*$ AND R. PARTON $\dagger$ \\ * Department of Medicine, Charing Cross Hospital Medical School, London W6 8RF, and \\ $\dagger$ Department of Microbiology, University of Glasgow, Glasgow G61 1QH
}

\section{Plates XV and XVI}

IT has long been known that many strains of gram-negative bacteria are insensitive to the bactericidal action of normal human serum despite the presence in the serum of bactericidal antibody and complement (Georgevitch, 1926; Mackie and Finkelstein, 1931); the nature of this resistance remains obscure. Serum resistance in Escherichia coli has been variously ascribed to the amount of cell-wall lipopolysaccharide (LPS), the length and number of LPS O-side chains and to both the amount and haemagglutination-inhibiting activity of acidic polysaccharide K antigen (see review by Inoue, 1972). In a recent study (Taylor, 1975), it was found that none of these factors was able to explain the behaviour of serum-resistant mutants derived from smooth, E. coli strains isolated from the urinary tract, and it was suggested that these mutants synthesised an additional surface component, possibly protein in nature, which was responsible for serum resistance.

The present study concerns the analysis of one of the serum-resistant mutants and the corresponding parent strain by gel-diffusion techniques and by sodium dodecyl sulphate (SDS)-polyacrylamide gel electrophoresis of cellenvelope proteins in an attempt to determine the basis of the mutation to serum resistance. Colonially rough mutants isolated from cultures of the serum-resistant mutant were also examined.

\section{Materials AND Methods}

Bacterial strains. E. coli no. LP729 is a smooth strain of serotype O9 which is rapidly killed by human serum after a delay of $1 \mathrm{~h} ; E$. coli no. $\mathrm{I} 7$ is a serum-resistant mutant derived from strain LP729 by mutagenesis with $\mathrm{N}$-methyl-N'-nitro-N-nitrosoguanidine (Adelberg, Mandel and Chen, 1965). Both strains produce negligible amounts of $\mathrm{K}$ antigen, are stable in $\mathbf{0 . 2 \%}$ acriflavine and synthesise LPS containing large amounts of mannose, a sugar confined to the O-side chain of LPS from E. coli O9 strains. E. coli nos. I7fa and $17 \mathrm{gb}$ are colonially rough mutants plated from an aged (4-week) nutrient-broth culture of strain 17. E. coli no. I7fa is rapidly killed by serum and is a $r f b$ mutant (Schmidt, Jann and Jann, 1969) with a complete LPS R2 core but defective in the synthesis of the LPS O9-side chain. Strain $17 \mathrm{gb}$ possesses a full complement of LPS O-side chains and interacts with serum in an identical way to strain LP729. Both colonially rough forms spontaneously agglutinate in $0 \cdot 2 \%$ acriflavine. Whereas strains LP729 and I7 are able to cause kidney infection in an experimental rat model, strains $17 \mathrm{fa}$ and $17 \mathrm{gb}$ are unable to do so (Taylor and Koutsaimanis, 1975). These strains are described in detail by Taylor (1975).

Received 13 July 1976; revised version accepted 8 Nov. 1976.

$\ddagger$ Present address: Sandoz Forschungsinstitut, A-1235 Wien, Brunner Strasse 59, Austria.

J. MED. MICROBIOL.-VOL. 10 (1977)

225 
Ouchterlony gel diffusion. Rabbit antisera against live and heat-killed $\left(100^{\circ} \mathrm{C} ; 1 \mathrm{~h}\right)$ bacteria were prepared according to the scheme of Schlecht and Westphal (1967). For the preparation of antigens, cells were cultivated in $2 \frac{1}{2}$-litre conical flasks containing $700 \mathrm{ml}$ of Nutrient Broth no. 2 (Oxoid) at $37^{\circ} \mathrm{C}$ in an orbital incubator $(120$ orbits per min.), washed with water and extracted with $10 \mathrm{ml}$ of $0 \cdot 2 \mathrm{M} \mathrm{LiCl}$ for $2 \mathrm{~h}$ in a reciprocating waterbath. It has recently been shown by Frasch and Gotschlich (1974) that extraction of gram-negative cells with $0 \cdot 2 \mathrm{M} \mathrm{LiCl}$ results in the efficient release of protein surface-antigens without significant cell lysis. Gel diffusion was carried out according to Grados and Ewing (1969).

Protease treatment. Proteolytic digestion of $\mathrm{LiCl}$-extracted antigens was performed with trypsin (BDH Chemicals Ltd, Poole, Dorset) and pronase (BDH) at an enzyme-to-antigenprotein ratio of $1: 10$ and the buffer systems described by Mescher, Strominger and Watson (1974). Mixtures were incubated at $37^{\circ} \mathrm{C}$ for up to $72 \mathrm{~h}$.

Gel filtration. Washed cells from a 15-litre nutrient-broth batch-culture $\left(37^{\circ} \mathrm{C} ; 16 \mathrm{~h}\right)$ were extracted with $100 \mathrm{ml}$ of $0.2 \mathrm{M} \mathrm{LiCl}$ for $2 \mathrm{~h}$ at $60^{\circ} \mathrm{C}$ in a reciprocating waterbath. After extensive dialysis against water at $4^{\circ} \mathrm{C}$, the extract was freeze-dried, suspended in $10 \mathrm{ml}$ of $0.15 \mathrm{M} \mathrm{NaCl}+0.01 \mathrm{M}$ Tris- $\mathrm{HCl}, p \mathrm{H} \mathrm{7.5}$, and applied to a column $(2.5 \mathrm{~cm} \times 60 \mathrm{~cm})$ of Sepharose 4B (Pharmacia Fine Chemicals AB, Uppsala, Sweden). The column was eluted with 0.15M $\mathrm{NaCl}+0.01 \mathrm{M}$ Tris- $\mathrm{HCl}, p \mathrm{H} \mathrm{7.5}$, at a flow rate of $20 \mathrm{ml}$ per h and $20-\mathrm{min}$. fractions were collected. The $\mathrm{E}_{280}$ of each fraction was determined, and the sugar content of each fraction measured by the phenol- $\mathrm{H}_{2} \mathrm{SO}_{4}$ technique (Dubois et al., 1956).

Envelope preparations. Cells were cultivated in 1-litre volumes of Nutrient Broth no. 2 (Oxoid) in 2-litre flanged conical flasks at $37^{\circ} \mathrm{C}$ in an orbital incubator (100 orbits per min.). After $4 \mathrm{~h}$, when cultures of all four strains had reached the late exponential phase, the cells were collected by centrifugation at $4^{\circ} \mathrm{C}$. Packed cells were resuspended in saline and, after freezing, were broken by three passages through an LKB X-press. After thawing, the suspensions were diluted with saline at $4^{\circ} \mathrm{C}$, mixed thoroughly with a syringe fitted with a 23-gauge needle and centrifuged at $100000 \mathrm{~g}$ for $30 \mathrm{~min}$. The resulting pellets were thoroughly dispersed in distilled water and recentrifuged. The deposits obtained were again suspended in water and centrifuged in a bench centrifuge for $10 \mathrm{~min}$. to remove unbroken cells and debris. The envelope fractions were then collected by centrifugation at $100000 \mathrm{~g}$ for $1 \mathrm{~h}$, dispersed in small volumes of water and frozen until required.

Electrophoresis. Slab gel electrophoresis with a discontinuous SDS buffer system was based on the method of Laemmli (1970) as modified by Ames (1974).

Separating and stacking gels contained $11 \%$ and $5 \%$ of acrylamide respectively. To dissolve the envelopes, a $0.5 \mathrm{-ml}$ sample containing $2 \mathrm{mg}$ of envelope protein was added to 0.5 $\mathrm{ml}$ of $0 \cdot 125 \mathrm{M}$ Tris- $\mathrm{HCl}$ buffer, $p \mathrm{H} 6 \cdot 8$, containing $4 \%$ of SDS, $10 \%$ of $\beta$-mercaptoethanol, $20 \%$ of glycerol and $0.002 \%$ of bromophenol blue, and the mixture was heated to $100{ }^{\circ} \mathrm{C}$ for 5 min. After electrophoresis, protein bands were stained with Coomassie Brilliant Blue R250 (B.D.H. Ltd) by the method of Weber and Osborn (1969). Carbohydrate-containing bands were stained by the periodic acid-Schiff (PAS) procedure according to Zacharius et al. (1969) as modified by Huang and Evans (1973). A full description of the electrophoretic procedures is given by Parton (1975).

\section{RESULTS}

\section{Gel diffusion of $\mathrm{LiCl}$ extracts}

It was previously suggested (Taylor, 1975) that the serum resistance of $E$. coli strain I7 was due to the presence of a surface component not found in the parent strain LP729. Therefore, $\mathrm{LiCl}$ extracts of the various strains were used in gel-diffusion studies with anti-I7 antisera. In initial experiments, bacteria were extracted with $\mathrm{LiCl}$ at $60^{\circ} \mathrm{C}$. With extracts from strains $\mathrm{I} 7, \mathrm{I} 7 \mathrm{gb}$ and I7fa, a precipitin line was consistently found close to the antiserum well when whole-cell antiserum was used; this line did not form against extracts 
from strain LP729 (fig. 1). The precipitin lines that formed near the antigen wells contained the O-antigen component. When the temperature of $\mathrm{LiCl}$ extraction was lowered to $45^{\circ} \mathrm{C}$, the inner precipitin line was evident only with extracts from strains 17 and $17 \mathrm{gb}$. However, when the extraction temperature was raised to $80^{\circ} \mathrm{C}$, all extracts formed the inner precipitin line with whole-cell antiserum against strain I7. Gel-diffusion patterns identical with those found with antisera against live and heat-killed strain-I7 cells were obtained with antisera produced against live and heat-killed strain-LP729 cells. The geldiffusion experiments were repeated with preparations obtained by extraction with $0.2 \mathrm{M} \mathrm{NaCl}$ at $45^{\circ} \mathrm{C}, 60^{\circ} \mathrm{C}$ and $80^{\circ} \mathrm{C}$; results were identical with those found with $0 \cdot 2 \mathrm{M} \mathrm{LiCl}$ extracts.

These results suggested that the mutation to serum resistance had resulted in a modification of the cell surface that enabled a particular antigen to be extracted from the cell mass at a lower temperature. Alternatively, the serumresistant mutant produced greater quantities of the antigen, and the absence of a precipitin line with strain LP729 was due to inadequate amounts of the antigen in the $45^{\circ} \mathrm{C}$ and $60^{\circ} \mathrm{C}$ extracts. The $60^{\circ} \mathrm{C}$ extracts from strain LP729 were concentrated up to 16-fold and examined by gel-diffusion with whole-cell antisera against strains I7 and LP729 in the usual way. With both antisera, a precipitin line, which formed a line of identity with the inner precipitin line in strain-I7 extracts, was found in 4-, 8- and 16-fold concentrates but was absent from 2-fold concentrates. This indicated that unconcentrated $60^{\circ} \mathrm{C}$ extracts of strain LP729 contained the antigen but in insufficient quantities to form a precipitin line.

The inner precipitin line did not form with $60^{\circ} \mathrm{C}$ extracts of strain 17 after

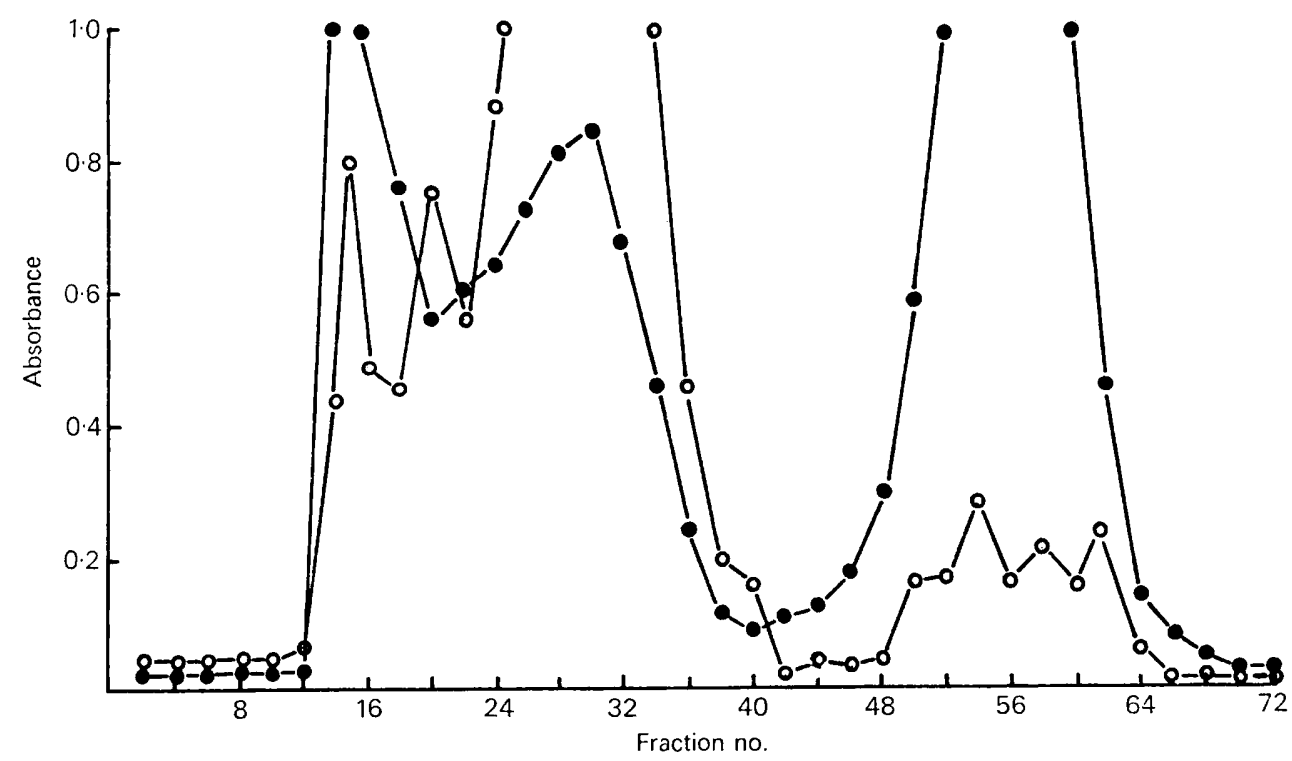

FIG. 2.-Fractionation of $0 \cdot 2 \mathrm{M} \mathrm{LiCl}\left(60^{\circ} \mathrm{C} ; 2 \mathrm{~h}\right)$ extract of $E$. coli strain $\mathrm{I} 7$ on Sepharose $4 \mathrm{~B}$. Fractions were examined by the phenol- $\mathrm{H}_{2} \mathrm{SO}_{4}$ technique and the absorbance at $490 \mathrm{~nm}(\mathrm{O}-\infty)$ measured. Fractions were also examined for absorbance at $280 \mathrm{~nm}\left(\mathrm{O}_{-}\right)$). 
treatment for $24 \mathrm{~h}$ with trypsin, but was still evident when extracts treated for $72 \mathrm{~h}$ with pronase were used. The antigen did not form lines of identity with material obtained by cetavlon precipitation of phenol-water extracts (Westphal and Jann, 1965) of strain 17 or strain LP729, and was non-dialysable. The antigen does not, therefore, represent the acidic polysaccharide $K$ antigen of the cell, but is a protein.

\section{Gel filtration of $60^{\circ} \mathrm{C} \mathrm{LiCl} \mathrm{extract}$}

An attempt was made to investigate further the nature of the antigen responsible for the inner precipitin line by subjecting a $60^{\circ} \mathrm{C} \mathrm{LiCl}$ extract of strain I7 to fractionation on a column of Sepharose 4B. Three major peaks were obtained (fig. 2). Fractions 14-40, comprising the first two peaks, reacted with $\mathrm{O}$ antiserum against strain $\mathrm{I} 7$ in gel-diffusion tests. The first peak, which was rich in $\mathrm{E}_{280}$ absorbing material, eluted with the void volume. Gel diffusion with whole-cell antiserum against strain I7 indicated that the antigen corresponding to the inner precipitin line appeared in fractions 43-50 and was the only detectable antigen present in fractions $43-46$ (fig. 3). Precipitin lines from these fractions formed lines of identity with the inner precipitin line from E. coli $1760^{\circ} \mathrm{C} \mathrm{LiCl}$ extracts of strain 17 .

Column fractions from the various peaks were pooled, dialysed against water and examined by SDS-polyacrylamide gel electrophoresis. Fig. 4 shows the protein compositions of fractions 13-20, 21-39 and 43-46 in comparison with the envelope-protein profile of strain I7. Fractions 43-46 contained one major band with an estimated molecular weight of 46000 daltons (46k) and only traces of other components. PAS staining failed to reveal the presence of carbohydrate-containing bands in the sample, so the $46 \mathrm{k}$ polypeptide component presumably represents the inner precipitin line antigen of the LiCl extract.

Fractions 13-20 and 21-39 contained several major polypeptide components including a 46k band (fig. 4). This and certain other bands both in the column fractions and in the envelope fraction were somewhat distorted. PAS staining of identical gels revealed the presence of several carbohydrate-containing bands in the same regions of the gels as the distorted polypeptide bands. Since the $46 \mathrm{k}$ polypeptide band in fractions $43-46$ was not distorted, and no carbohydrate-containing bands were detected in this sample, the presence of the carbohydrate bands in the other samples may have been responsible in some way for the distortion of the polypeptide bands.

Although fractions 13-20 and particularly fractions 21-39 apparently contained the 46k component, which was also found in fractions $43-46$, they did not form the inner precipitin line in gel-diffusion tests against whole-cell antiserum. They did, however, react with $\mathrm{O}$ antiserum in these tests. Thus, in these fractions, the $46 \mathrm{k}$ polypeptide was presumably complexed with other components such as LPS and so was unable to form a discrete precipitin line. Evidence for such a complex was obtained by gel-diffusion studies of fractions 13-20 and 21-39 after heat treatment at $100^{\circ} \mathrm{C}$ for varying periods of time. With both pools the inner precipitin line appeared after heating for $5 \mathrm{~min}$. 
and increased in intensity as the heating period was extended to $30 \mathrm{~min}$. Two additional precipitating antigens not found in the original $60^{\circ} \mathrm{C} \mathrm{LiCl}$ extracts were also evident in both pools after $30 \mathrm{~min}$. at $100^{\circ} \mathrm{C}$.

\section{Comparison of envelope-protein profiles}

The envelope-protein profiles of all four $E$. coli strains are shown in fig. 5. Distorted bands were repeatedly obtained in the profiles of strains LP729, I7 and $\mathrm{I} 7 \mathrm{gb}$. PAS staining revealed carbohydrate-staining material in the same region of the gel and this, as suggested above, may have interfered in some way with the migration of the polypeptides during electrophoresis. This was also suggested by the finding that the protein profile of strain I7fa was not distorted and no carbohydrate-staining material was detected in the gel.

Despite the problem of band distortion, the protein profiles of strains LP729 and I7 were indistinguishable. There were no apparent differences in envelope-protein composition that could account for the difference in serum sensitivity between the two organisms. Strain $\mathrm{I7gb}$, which is morphologically rough but has complete LPS O-side chains, had a similar profile but possessed an extra band at $41 \mathrm{k}$ and showed other minor differences. Strain I7fa, the rough strain that lacks the LPS O-side chains, appeared to be quite different from the other three strains though this may in part be due to the lack of band distortion in this profile. One obvious difference, however, was that I7fa envelopes lacked a prominent band at $31 \mathrm{k}$ which was present in all of the other three strains.

It should be noted from fig. 5 that the envelope of all four strains contained approximately equal amounts of the $46 \mathrm{k}$ polypeptide band, the only significant band found in column fractions $43-46$.

\section{Discussion}

Previous studies with these strains had demonstrated that no gross changes in the lipopolysaccharide or acidic polysaccharide components of the bacterial wall had occurred to account for the mutation to serum resistance, although it did appear that lipopolysaccharide $\mathrm{O}$-side chains were responsible for a delay in the serum killing of the parent strain LP729 (Taylor, 1975). The immunogeldiffusion studies were therefore instigated in an attempt to determine whether the serum-resistant mutant produced antigens not found in strain LP729. The $60^{\circ} \mathrm{C} \mathrm{LiCl}$ extracts of the serum-resistant mutant $\mathrm{I} 7$ gave rise to a precipitin line not found with extracts of the parent strain LP729, although further experiments indicated that LP729 extracts contained the antigen but in insufficient quantity to form lines of precipitation. One interpretation of these results is that strain 17 produces greater quantities of the protein antigen than strain LP729, and we suggest that this protein is responsible for the serum resistance of strain I7. The present results do not, however, exclude the possibility that a subtle modification in the arrangement of surface components is responsible for the differences in extractibility of the antigen and for differences in serum sensitivity. If the $46 \mathrm{k}$ envelope-protein band represents the same polypeptide 
in all samples, the antigen responsible for the inner line of precipitation appears to be present in approximately equal amount in the envelopes of all four strains (fig. 5). The composition of cell-envelope proteins, however, may not be a true reflexion of the composition of the cell surface; for example, surface material may be washed off during envelope preparation. In addition, the $46 \mathrm{k}$ antigen band responsible for the inner precipitation line may have coincided with a more prominent envelope band; changes in the quantity of the antigen might not, therefore, be easily detected in the envelope profiles.

No direct evidence was obtained for the position of the antigen within the bacterial cell, but the fact that it was able to evoke a strong antibody response after inoculation of live cells into rabbits and that it could be extracted from the cell mass under relatively mild conditions suggests that it is present at or near the cell surface. The presence of such a component would accord with the generally held view that serum resistance is due to the presence of adequate amounts of structures which impede the attachment or subsequent activity of antibody and complement (Wardlaw, 1964; Glynn and Howard, 1970). It is clear that the presence of the antigen in amounts comparable with those found in strain I7 is not alone sufficient to render a strain resistant to serum. Strains $17 \mathrm{gb}$ and $\mathrm{I} 7 \mathrm{fa}$ appear to contain more of the antigen in a readily extractable form than strain LP729 but are serum sensitive, indicating that the presence of other cell-surface components, such as lipopolysaccharide O-side chains, is essential for expression of full serum resistance. The only major component of fractions 43-46 obtained by Sepharose 4B chromatography (figs. 2 and 3) was a protein with an apparent molecular weight of $46 \mathrm{k}$ daltons, and it is likely that this protein represents the antigen of the inner precipitation line in strain- $\mathrm{I} 7 \mathrm{LiCl}$ extracts.

Although it has been previously suggested that serum resistance is due to the presence of abundant amounts of LPS O-side-chain material (Feingold, 1969 ) and to the amount of acidic polysaccharide $K$ antigen associated with the cell (Glynn and Howard, 1970; Howard and Glynn, 1971) these theories fail to explain a number of observations. Nelson and Roantree (1967) isolated serum-sensitive mutants from serum-resistant strains of Salmonella typhimurium and S. enteritidis. The majority were rough or part rough, but sensitive mutants that were found to be culturally and serologically smooth had LPS with ratios of O-side-chain sugar to core sugar identical with those of the LPS of the parent strains. Current theories were also unable to explain the serum reactivity of 28 smooth strains of $E$. coli isolated from patients with urinary-tract infections (Taylor, 1976). Taylor (1975) found that recombinants that had inherited a full complement of O8-specific LPS side chains from a K-negative, serumresistant, Hfr E. coli donor strain were sensitive to serum. Many gram-negative bacteria synthesise no $\mathrm{K}$ antigen and yet are resistant to serum. Klebsiella strains are frequently found to be sensitive to serum (Fierer, Finley and Braude, 1972) even though most strains of this genus produce copious amounts of hexuronic-acid-containing acidic polysaccharide (Sutherland, 1972).

Recent findings have shown that smooth-to-rough variation involves changes in envelope-protein composition as well as in LPS composition (Ames, 

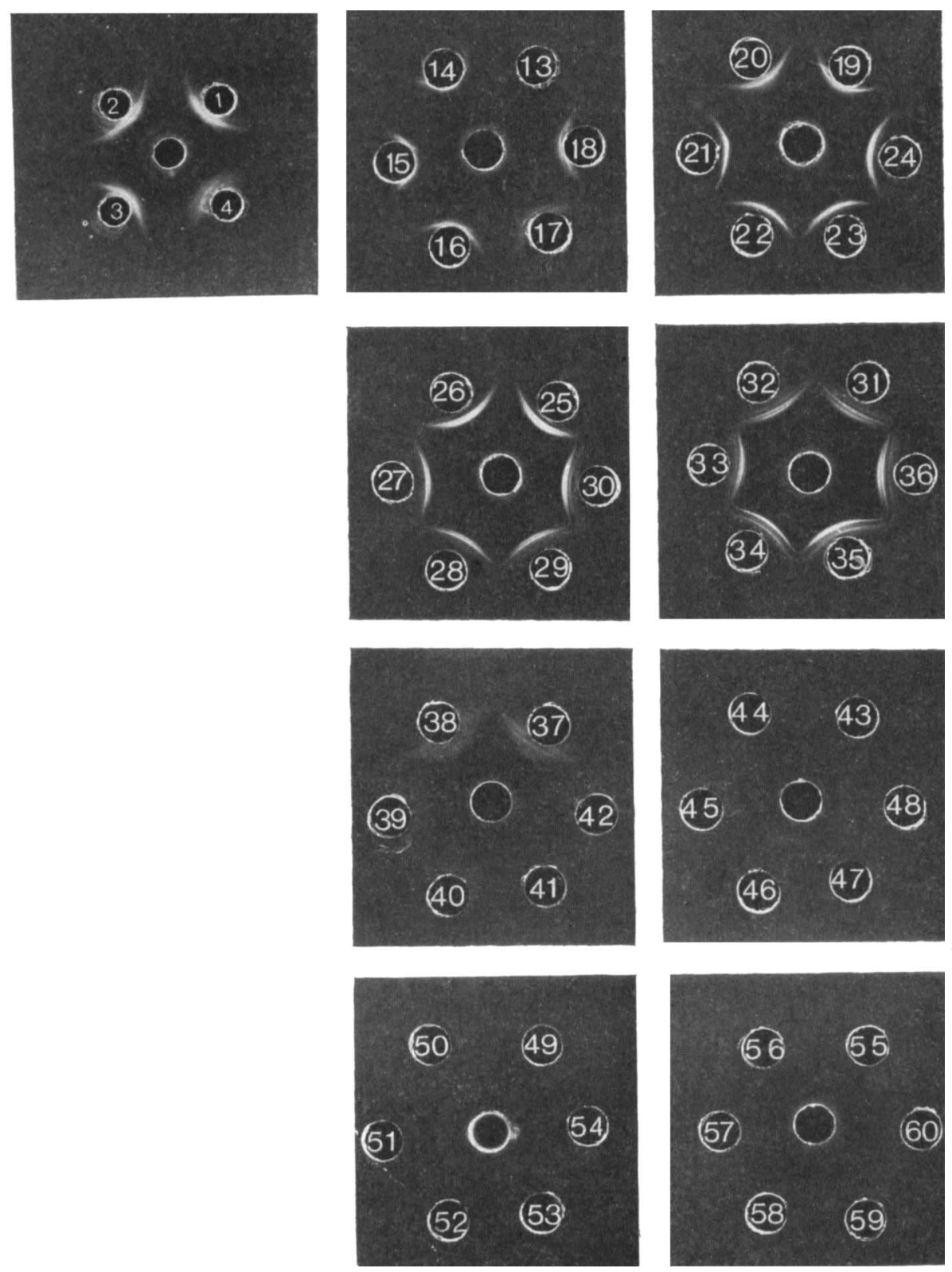

FIG. 1 (top left).-Immunogel-diffusion patterns obtained with $0.2 \mathrm{M} \mathrm{LiCl}$ extracts $\left(60^{\circ} \mathrm{C} ; 2 \mathrm{~h}\right)$ of Escherichia coli strains (1) LP729, (2) I7, (3) I7gb and (4) I7fa. The centre well contained antiserum ( $4: 1$ concentration) prepared against live cells of strain 17 .

FIG. 3.- Immunogel-diffusion patterns of fractions 13-60 obtained by chromatography of $0 \cdot 2 \mathrm{M}$ $\mathrm{LiCl}\left(60^{\circ} \mathrm{C} ; 2 \mathrm{~h}\right)$ extract of $E$. coli strain 17 on Sepharose $4 \mathrm{~B}$. The centre wells contained antiserum ( $4: 1$ concentration) prepared against live cells of the same strain. 
Serum Resistance in $E$. COLI
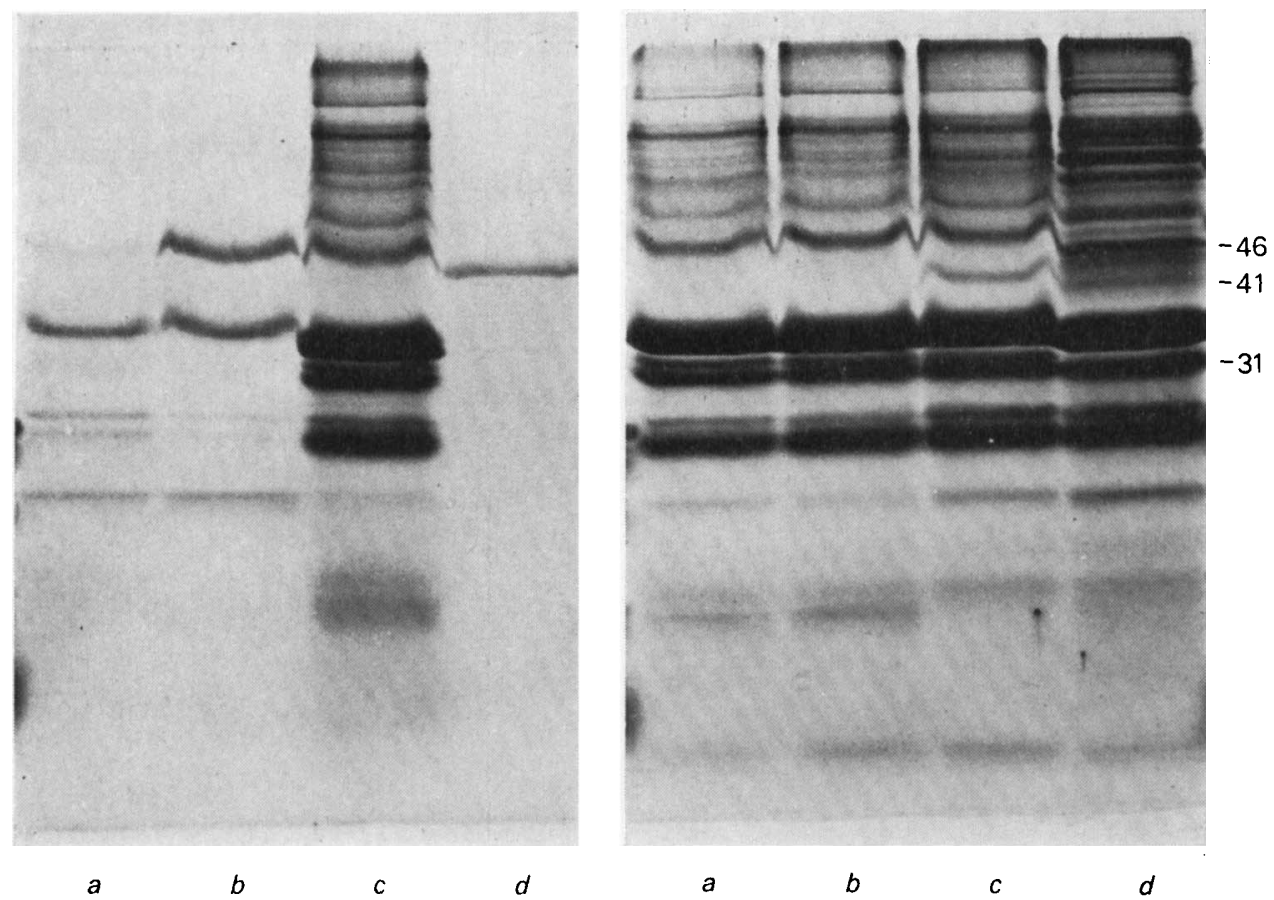

FIG. 4 (left).-Protein compositions of (a) column fractions 13-20, (b) fractions 21-39 and (d) fractions 43-46; for comparison, $(c)$ envelope-protein profile of strain 17 by SDS-polyacrylamide gel electrophoresis.

Frg. 5 (right).-Envelope-protein profiles of $E$. coli strains (a) LP729, (b) I7, (c) 17gb, (d) I7fa. Molecular weight (k-daltons) of various bands are given on the right. 
Spudich and Nikaido, 1974; Koplow and Goldfine, 1974; Parton, 1975). Changes in sensitivity to antibiotics, dyes, etc., and in serum sensitivity during smooth-to-rough variation have been attributed in the past to changes in LPS composition. It is now evident that further investigation of the role of envelope proteins is likely to lead to a more complete understanding of these phenomena.

Of interest was the observation that O-antigen-containing components of the $60^{\circ} \mathrm{C} \mathrm{LiCl}$ extract of strain $\mathrm{I} 7$ could be resolved into two distinct fractions by chromatography on Sepharose 4B (fig. 2). The first, high-molecular-weight peak contained large amounts of $\mathrm{E}_{280}$ absorbing material, presumably protein, and relatively small amounts of carbohydrate, and was excluded from the gel. The second peak, which was retarded by the gel, contained greater amounts of carbohydrate and less of protein. Gel electrophoresis indicated that the two peaks also had a slightly different protein composition (fig. 4).

It was previously suggested (Taylor, 1975; Taylor and Koutsaimanis, 1975) that the rough characteristics of strain $17 \mathrm{gb}$, and its failure to cause kidney infection in experimentally infected rats, might be due to the loss of a single protein factor from the cell surface. The results of gel electrophoresis of envelope proteins (fig. 5) indicate that the explanation is likely to be more complex. A number of minor differences were found between the envelope profiles of strains $\mathrm{I} 7$ and $17 \mathrm{gb}$, including the appearance of an extra band in the $I 7 \mathrm{gb}$ profile. It is not known whether these differences are related in any way to the other differences between the strains.

\section{SUMMARY}

Immunogel-diffusion studies showed that $60^{\circ} \mathrm{C} \mathrm{LiCl}$ extracts of the smooth serum-resistant mutant Escherichia coli strain 17 contained greater amounts of a protein antigen than did extracts of the parent strain LP729. An extract of strain $\mathrm{I} 7$ was fractionated on Sepharose 4B and the protein antigen was found as the only detectable antigen in a number of fractions; sodium dodecyl sulphate-polyacrylamide gel electrophoresis indicated that these fractions contained one major polypeptide band with a molecular weight of 46000 daltons. We suggest that this protein antigen may be partly responsible for the serum resistance of strain 17 though its presence in other serum-sensitive strains suggests that additional factors are essential for full serum resistance.

\section{REFERENCES}

Adelberg, E. A., Mandel, M. And Chen, G. C. C. 1965. Optimal conditions for mutagenesis by $N$-methyl- $N^{\prime}$-nitro- $N$-nitrosoguanidine in Escherichia coli K12. Biochem. biophys. Res. Commun., 18, 788.

AMES, G. F. 1974. Resolution of bacterial proteins by polyacrylamide gel electrophoresis on slabs. Membrane, soluble and periplasmic fractions. J. biol. Chem., 249, 634.

Ames, G. F., Spudich, E. N. ANd Nikaido, H. 1974. Protein composition of the outer membrane of Salmonella typhimurium: effect of lipopolysaccharide mutations. J. Bact., 117, 406.

Dubois, M., Gilles, K. A., Hamilton, J. K., Rebers, P. A. and Smith, F. 1956. Colorimetric method for determination of sugars and related substances. Analyt. Chem., 28,350 .

FeINGold, D. S. 1969. The serum bactericidal reaction. IV. Phenotypic conversion of 
Escherichia coli from serum-resistance to serum-sensitivity by diphenylamine. J. infect. Dis., $120,437$.

Fierer, J., Finley, F. AND Braude, A. I. 1972. A plaque assay on agar for detection of Gram-negative bacilli sensitive to complement. J. Immun., 109, 1156.

Frasch, C. E. AND Gotschlich, E. C. 1974. An outer membrane protein of Neisseria meningitidis group B responsible for serotype specificity. J. exp. Med., 140, 87.

Georgevitch, A. 1926. Sur le pouvoir bactéricide du sérum humain normal. C. r. Séanc. Soc. Biol., 95, 954.

GlynN, A. A. AND HowARD, C. J. 1970. The sensitivity to complement of strains of Escherichia coli related to their $\mathrm{K}$ antigens. Immunology, $18,331$.

Grados, O. AND EwING, W. H. 1969. Technics for characterization of soluble antigens of Enterobacteriaceae. U.S. Department of Health, Education and Welfare, Public Health Service, National Communicable Disease Center, Atlanta, Ga.

Howard, C. J. AND GlYNN, A. A. 1971. Diphenylamine induced complement sensitivity and associated changes in antigenic structure of Escherichia coli. Immunology, 21, 951.

HuANG, F. L. AND Evans, W. H. 1973. Differences in protein and glycoprotein patterns between mature and immature neutrophil leukocytes. Biochim. biophys. Acta, 317, 394.

INOUE, K. 1972. Immune bacteriolytic and bactericidal reactions. In Research in immunochemistry and immunobiology, vol. 1, edited by J. B. G. Kwapinski, Baltimore, p. 177.

Koplow, J. AND GoldFINE, H. 1974. Alterations in the outer membrane of the cell envelope of heptose-deficient mutants of Escherichia coli. J. Bact., 117, 527.

LAEMMLI, U. K. 1970. Cleavage of structural proteins during the assembly of the head of bacteriophage T4. Nature, Lond., 227, 680.

MACKIE, T. J. AND FINKELSTEIN, M. H. 1931. Natural bactericidal antibodies: observations on the bactericidal mechanism of normal serum. J. Hyg., Camb., 31, 35.

Mescher, M. F., Strominger, J. L. and Watson, S. W. 1974. Protein and carbohydrate composition of the cell envelope of Halobacterium salinarum. J. Bact., 120, 945.

Nelson, B. W. AND RoANTREe, R. J. 1967. Analyses of lipopolysaccharides extracted from penicillin-resistant, serum-sensitive Salmonella mutants. J. gen. Microbiol., 48, 179.

PARTON, R. 1975. Envelope proteins in Salmonella minnesota mutants. J. gen. Microbiol., 89, 113.

SChlECht, S. AND WestPhal, O. 1967. Über die Herstellung von Antiseren gegen die somatischen (O-) Antigene von Salmonellen. I. Untersuchungen über Agglutinintiter. Zentbl. Bakt. ParasitKde, I. Abt. Orig., 204, 335.

SCHMIDT, G., JANN, B. AND JANN, K. 1969. Immunochemistry of R lipopolysaccharides of Escherichia coli: different core regions in the lipopolysaccharides of $\mathrm{O}$ group 8. Eur.J. Biochem., 10, 501.

SUTHERLAND, I. W. 1972. Bacterial exopolysaccharides. In Advances in microbial physiology, vol. 8, edited by A. H. Rose and D. W. Tempest, London, p. 143.

TAYLOR, P. W. 1975. Genetical studies of serum resistance in Escherichia coli. J. gen. Microbiol., 89, 57.

TAYLOR, P. W. 1976. Immunochemical investigations on lipopolysaccharides and acidic polysaccharides from serum sensitive and serum resistant strains of Escherichia coli isolated from urinary tract infections. J. med. Microbiol., 9, 405.

Taylor, P. W. AND Koutsaimanis, K. G. 1975. Experimental Escherichia coli urinary infection in the rat. Kidney Internat., 8, 233.

Wardlaw, A. C. 1964. Endotoxin and complement substrate. In Bacterial endotoxins, edited by M. Landy and W. Braun, Rutgers, p. 81 .

WeBER, K. AND OsBORN, M. 1969. The reliability of molecular weight determinations by dodecyl sulphate-polyacrylamide gel electrophoresis. J. biol. Chem., 244, 4406.

WESTPHAL, O. AND JANN, K. 1965. Bacterial lipopolysaccharides: extraction with phenolwater and further applications of the procedure. In Methods in carbohydrate chemistry, vol. 5, edited by R. L. Whistler, London, p. 83.

Zacharius, R. M., Zell, T. E., Morrison, J. H. AND Woodlock, J. J. 1969. Glycoprotein staining following electrophoresis on acrylamide gels. Analyt. Biochem., 30, 148. 